BLS 32, No 1 2006. DOI: http://dx.doi.org/10.3765/bls.v32i1.343 (published by the Berkeley Linguistics Society and the Linguistic Society of America)

\title{
Predicting the Productivity of Argument Structure Constructions
}

\author{
JÓHANNA BARĐDAL \\ University of Bergen / University of California, Berkeley
}

\section{Introduction}

Productivity has been a much-debated concept within morphology and word formation for years, while syntactic productivity has received little attention in the research community. In mainstream syntax the concept of syntactic productivity is focused on speakers' ability to generate and understand sentences never encountered before. This notion of productivity captures what has been labeled 'linguistic competence' within the generative paradigm, but does not address the interesting question of how case and argument structure constructions are extended to new verbs. A usage-based construction grammar that takes argument structure constructions to exist at different levels of schematicity offers an account of that. I argue that productivity is a function of type frequency and coherence (i.e. internal consistency) and that the productivity of argument structure constructions is predictable from their type frequency and semantic coherence, and an inverse correlation between the two. Such a view offers a unified account of the complexity of the productivity concept, including the relation between the different subconcepts of productivity, i.e. those of regularity, generality, and extensibility. Also, facts of different degrees of productivity as well as analogy fall out directly from this approach.

\section{The Concepts of Productivity}

In my work on the productivity of argument structure constructions, I have found that the concept of productivity is a highly complex and multi-faceted one (Barðdal 2000:23-5, 2008). Not only are the terms productive and productivity used in many different senses in the linguistic literature, but there are at least three different subconcepts of the productivity concept around (cf. Barðdal 2008:Ch. 2). Consider the following statements, all from Bybee (1995): 
Jóhanna Barðdal

Clahsen and Rothweiler present considerable evidence that the productive or regular affix for past-participles in German is the $-t$ affix ... Thus they claim that the determinant of productivity or regularity is not type frequency. (Bybee 1995:435)

... certain classes of verbs within the irregulars show some degree of productivity - that is, the ability to be extended to new items. (Bybee 1995:426)

The first quote above illustrates that productivity has been equated with default status in the literature, but default status is generally considered a consequence of how open or general a pattern is. In the second quote, regular is used synonymously with productive. In the third quote, productivity is defined as the ability of a pattern to be extended to new items. The use of the terms productive and productivity in the three quotes above are by no means unique in the literature. I have found these terms used in at least nineteen different senses in the linguistic literature alone (Barðdal 2008:Ch. 2), and all nineteen can be related in one way or another to the concepts of generality, regularity, and extensibility. This suggests that the productivity concept consists of at least three different subconcepts, namely the following:

1. Productivity as GENERALITY

2. Productivity as REGULARITY

3. Productivity as EXTENSIBILITY

The reason that these three concepts have become associated with productivity is presumably that they all co-occur in the largest and most productive categories discussed in the literature. Consider, for instance, regular past-tense formation in English, materialized with the dental suffix -ed. Approximately $96 \%$ of all English verbs form past tense with this suffix (Ragnarsdóttir, Simonsen, and Plunkett 1999). This past-tense formation is also the one extended most to both new and nonce verbs, and the one that has attracted most verbs from other patterns in the history of English. This pattern is totally regular, with the suffix -ed attached to the stem. There are, moreover, no semantic, morphological, or phonological constraints on which verbs can form past tense in this way. Hence, this is a completely general pattern. Therefore, in the category of regular verbs in English all three subconcepts of productivity - REGULARITY, GENERALITY, and EXTENSIBILITY are combined.

Figure 1. The three subconcepts of productivity

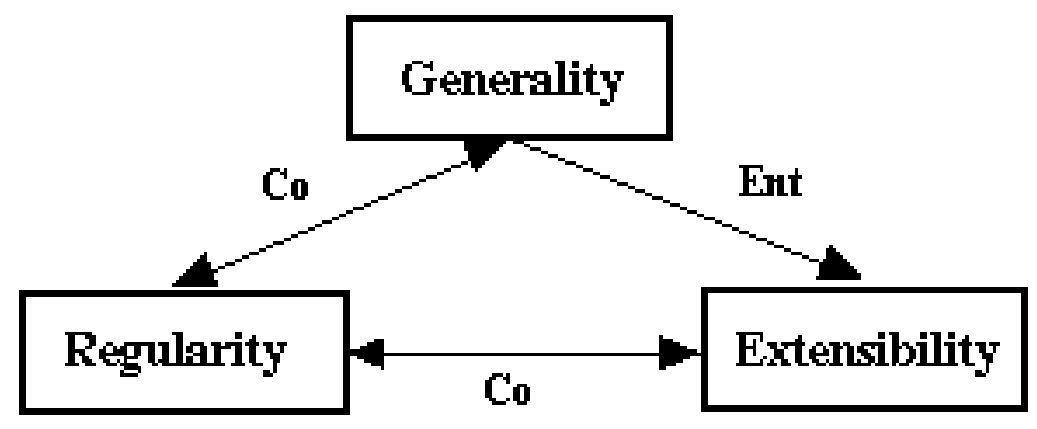


The relation between the subconcepts can be modeled as in Figure 1 above. The most regular patterns in a language are usually also the most general patterns. Hence, these two properties are often concomitant with each other, represented with $C o$ in Figure 1 for 'concomitance relation'. The most regular pattern is also the one that is most extended to either new or existing items in a language, exactly as the most extensible pattern is usually the most regular pattern. REGULARITY and EXTENSIBILITY are therefore concomitant with each other, even though they are not logically dependent on each other. The most general pattern is usually also the most extensible pattern, whereas extensible patterns need not be the most general ones. This is indicated with Ent for 'entailment relation' in Figure 1. In other words, GENERALITY entails EXTENSIBILITY, whereas EXTENSIBILITY does not presuppose GENERALITY, as restricted patterns can also be extended to new or existing items, although they are extended much less than non-restricted patterns. In the next section, I will show that the REGULARITY and the GENERALITY subconcepts can be treated as derivatives of the EXTENSIBILITY concept of productivity.

\section{Predicting Productivity}

Following Bybee (1995) and Clausner and Croft (1997), I assume that productivity is a function of type frequency and coherence, i.e. internal consistency, and that there is an inverse correlation between the two. For a category that is high in type frequency, this means that only a low degree of internal consistency across its items is needed for the category to be extended. Categories of intermediate type frequency have to be more coherent than high type-frequency categories in order to be extended to new items. Finally, categories that are low in type frequency must show the highest degree of internal consistency across their items in order to be extended to new types. This can be represented graphically as in Figure 2 below, where the vertical axis stands for type frequency and the horizontal one for coherence, in this case semantic coherence, as argument structure constructions are regarded as semantically defined (form-meaning correspondences) in a usagebased construction grammar (Goldberg 1995; Barðdal 2001a, 2001c, 2004, 2006; Barðdal and Molnar 2003; Croft 2001, 2003). Observe that high type-frequency patterns are located at the upper leftmost end of the productivity cline in Figure 2, as the patterns highest in type frequency also show the lowest degree of coherence, exactly because of their high type frequency. Patterns lower in type frequency will be located lower on the vertical axis, and the higher the degree of coherence found across their instantiating items, the closer they are to the productivity cline going from the upper leftmost corner to the lower rightmost corner in Figure 2.

What, then, about the lower rightmost end of the productivity cline in Figure 2? How does productivity manifest itself there? Obviously, the lowest possible type frequency is only one, and the highest possible degree of semantic coherence is full synonymy. In other words, only one item will be needed as a model for the extensibility of a pattern to a new lexical item, if the degree of semantic coherence 
is high enough. Such a process is usually labeled 'analogy' in the linguistic literature and considered as fundamentally different from productivity (cf. Bauer 2001:93). On the present approach, however, full productivity and analogy are two sides of the same coin, not different in ontological status but in degree. I return to this issue in section 3 below.

Figure 2. The inverse correlation between type frequency and coherence

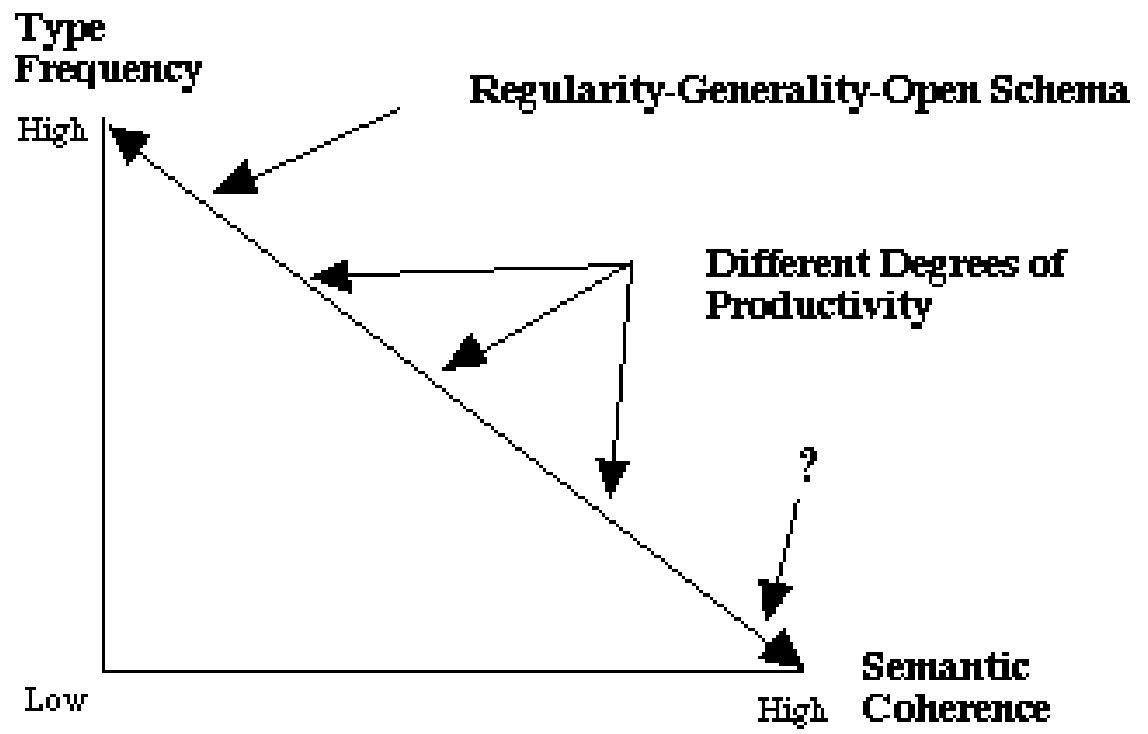

Observe that at the top of the productivity cline where we find the most extensible categories, we also find the most general and the most regular categories in languages. Hence, not only does the present model of productivity based on the EXTENSIBILITY concept provide us with the cline from full productivity via different degrees of productivity to analogical extension, the subconcepts of REGULARITY and GENERALITY can also be derived from it.

I assume, moreover, that constructions exist at different levels of schematicity in the schematicity-lexicality continuum (Croft 2003; Barðdal 2000, 2001a, 2004, 2006). The lowest level consists of concrete, lexically filled instantiations of the construction; the next level above that contains verb subclass-specific constructions; the next level contains verb class-specific constructions; and the level above contains event-type constructions, etc. Hence, every level above the lowest, most concrete level is an abstraction across the items of the level below. The lowest level contains the most lexical and semantic information, whereas the highest, most schematic level contains the least lexical and semantic information. This is the most abstract level, hence the term 'schematic'. This organization of argument structure constructions is given in Figure 3 below for two argument structure constructions differing in type frequency and hence in the number of intermediate levels, as well as in their highest level's degree of schematicity. 
Figure 3. Different levels of schematicity and, thus, productivity
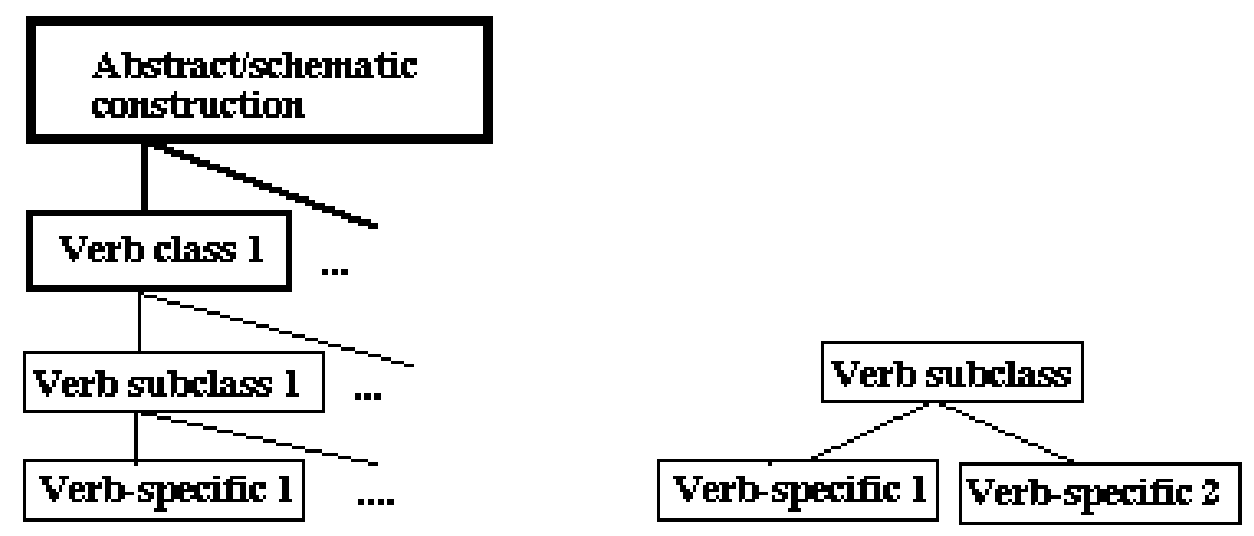

Observe that on this bottom-up approach, the highest level of schematicity is derived from the lower levels. That is, as every level is an abstraction of its subordinate level, each construction's highest level is dependent on the number of intermediate levels. These in turn are highly dependent on the type frequency of each construction. To give an example, compare the type frequency of the ditransitive construction in English with that of the transitive construction. Goldberg (1995: 129) lists 69 ditransitive verbs divided across nine semantic verb classes. This means that there are at least 69 verb-specific constructions of the ditransitive construction in English and at least nine verb subclass-specific constructions. Some of the nine verb classes belong more closely together semantically than others. For instance, verbs of giving, ballistic motion, and bringing all entail that the agent successfully causes the recipient to receive the moved object. Verbs of creation and obtaining both entail intended transfer (Goldberg 1995:37-9). This means that the verb class-specific constructions are only six, as some of the verb subclass-specific constructions are subsumed under the more abstract verb classspecific constructions. All the six verb class-specific constructions are based on the notion of transfer; hence, the ditransitive construction's highest and most schematic level only contains information about the event type 'transfer'. '

Compare now the ditransitive construction with the ordinary transitive. Although I am not aware of any counts of the type frequency of the transitive construction in English, I have carried out a count of the type frequency of the transitive construction in Icelandic. A simple count based on a bilingual IcelandicEnglish dictionary yields 2,119 verbs (see Table 1 below). This is probably the lowest possible estimate of the type frequency of the transitive construction in Icelandic, and there is no reason to assume that there are any fewer transitive verbs in English. A type frequency of approximately 2,100 yields around 2,100

\footnotetext{
${ }^{1}$ See, however, Barðdal (2007) for a comparative analysis of the ditransitive construction in Germanic, where it is argued that the semantic scope of the ditransitive stretches far beyond the notion of transfer, not only in Icelandic, Mainland Scandinavian, and German, but also in English.
} 
verb-specific constructions at the bottom of the schematicity-lexicality continuum; hence, the verb subclass-specific constructions are bound to be considerably more than nine for the transitive. This also means that there are many more intermediate levels of schematicity found for the transitive than the ditransitive, and the event-type level will denote many more event types than only transfer. Thus, the transitive construction's highest level of schematicity is bound to be considerably higher and more schematic than the highest level of the ditransitive. The proportion between the transitive and the ditransitive may thus correspond approximately to the proportions between the two hypothetical constructions in Figure 3. As a consequence, the transitive construction should be much more productive than the ditransitive, as the former exists at a much higher level in the schematicity-lexicality continuum. In other words, the productivity of each construction is a derivative of the construction's highest level of schematicity.

Clausner and Croft (1997) take productivity to be predictable not from a construction's highest level of schematicity, but from its most entrenched level. They suggest a representation of gradient productivity as in Figure 4 below:

Figure 4. Gradient productivity on Clausner and Croft's (1997:271) approach

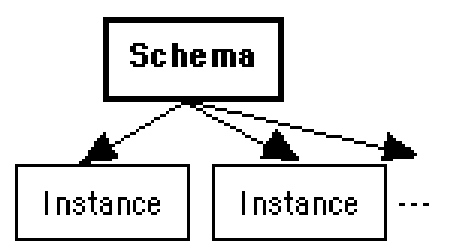

(a) Productive

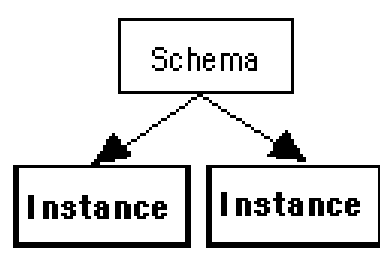

(b) Semi-productive
Ingtance

(c) Unproductive

To give an example, consider English past-tense formation again. The regular past-tense formation with the dental suffix -ed is definitely the highest one in type frequency, which in practice means a highly entrenched schema and full productivity (4a). The irregular past-tense formation with vowel change in the stem is very low in type frequency, although the instances are very high in token frequency (4b). This means that it is not the schema that is entrenched but the instances, resulting in low productivity. Finally, suppletive forms, like go-went, are completely idiosyncratic; thus, they do not form a schema and are as such unproductive (4c). Hence, it is the most entrenched level of schematicity that is the best predictor of productivity; if it is the schema the pattern will be productive, whereas if it is the instances the pattern will be unproductive.

While I agree with Clausner and Croft, and Bybee, in principle, I disagree with them on which factor is predictive of productivity. They argue that it is each construction's most entrenched level, while I claim that it is each construction's highest level of schematicity. On their view, the irregular past-tense formation in English is only semi-productive because the instances are so high in token frequency, which in turn means that it is the lowest verb-specific level that is en- 
trenched and not the higher schematic level. In contrast, I argue that the irregular past-tense formation is low in productivity because its highest level of schematicity is much lower than that of the regular past-tense formation. Hence, I believe that the gradience of productivity is better represented as in Figure 5.

Figure 5. Gradient productivity on the present approach

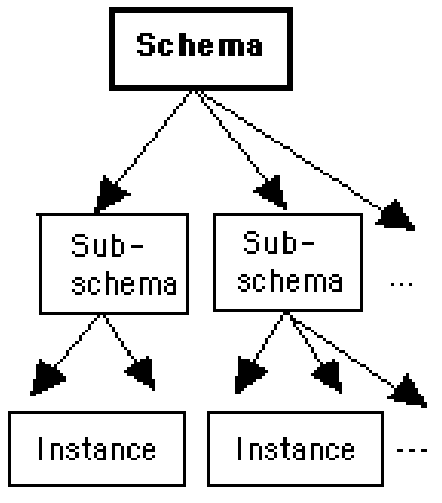

(a) Productive

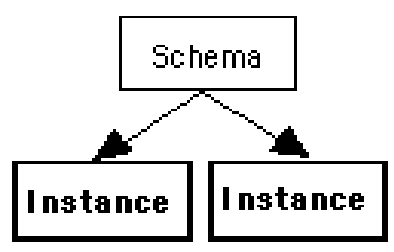

(b) Semi-productive

\section{Ingtance}

(c) Unproductive

This figure better captures the fact that the differences in type frequency found for highly productive vs. semi-productive patterns also entail the existence of intermediate schematic levels for the more productive pattern, which again results in a higher level of schematicity for highly productive constructions, but a lower level of schematicity for semi-productive constructions. Hence, the difference between highly productive and semi-productive patterns is not necessarily a difference in the entrenchment of a super-ordinate level, but rather a difference in both the type frequency of the two constructions and in the levels of schematicity at which they exist. This last fact, that a schema's type frequency and its degree of schematicity are to a large extent concomitant with each other, at least for high type-frequency constructions, is not adequately represented in Figure 4.

I now turn to the productivity of case and argument structure constructions in Icelandic.

\section{Productivity of Argument Structure Constructions}

In order to study the productivity of argument structure constructions, I have collected verbs from the area of information technology borrowed into Icelandic. I mostly confine my material to the borrowings I found at the discussion forum for Icelandic Mac users. Only transitive argument structure constructions are included, but as is well known, Icelandic has several case-marking patterns for twoplace predicates, including Nom-Acc, Nom-Dat, and Nom-Gen (cf. Barðdal 2001b:51-6). These borrowings are listed in (1) and (2) below (spelling original): 


\section{Jóhanna Barðdal}

(1) Nom-Acc: archive-a 'archive', battla 'battle', biddsslappa 'bitchslap', blasta 'blast', bojkotta 'boycott', builda 'build', bomba 'bomb', branda 'brand', browsa 'browse', bösta 'bust', compilera 'compile', copy-a 'copy', digga 'dig', döbba 'dub', editera 'edit', erasa 'erase', fila 'like', fixa 'fix', flexa 'flex', formatta 'format', fótósjoppa 'photoshop', gúggla 'google', hakka 'hack', hössla 'hustle', kidda 'kid', krakka 'crack', logga 'log', massa 'finish with style', meisa 'spray with tear gas', modda 'modify', mounta 'mount', muffa 'bang', mönnsa 'munch', offa 'off', óna 'own', paira 'pair', partiona 'partition', patcha 'patch', peista 'paste', pinga 'ping', plögga 'plug', pródúsera 'produce', prógrammera 'program', publisha 'publish', r[e]nta 'rent', releasa 'release', rendera 'render', resetta 'reset', resolva 'resolve', restora 'restore', rippa 'rip', rokka 'rock', skratsa 'scratch', skvassa 'squash, break', slamma 'slam', ssh-a 'shh', stúdera 'study', supporta 'support', sörfa 'surf', synca/synkrónisera 'synchronize', tagga 'tag, write', testa 'test', tóka 'smoke hash', trimma 'trim', updata 'update', upgreida 'upgrade', verifya 'verify' ...

(2) Nom-Dat: adda 'add', blasta 'blast', bomba 'bomb', bundla 'bundle', convertera 'convert', downloada 'download', deleta 'delete', demultiplexa 'de-multiplex', dumpa 'dump', droppa 'drop', ejecta 'eject', expandera 'expand', exporta 'export', farta 'fart', innstalla/innstallera 'install', krassa 'crash', msna 'MSN', mökka 'contaminate', neimdroppa 'namedrop', offa 'off', parkera 'park', peista 'paste', poppa 'deliver when popping by', pósta 'post', publisha 'publish', releasa 'release', resolva 'resolve', restarta 'restart', rippa 'steal', sjera 'share', slamma 'slam', starta 'start', statta 'stat, duplicate', streyma 'stream', tilta 'tilt', umba 'be agent for', unzippa 'unzip', uploada 'upload', untara 'unzip' ...

It is worth pointing out that the verbs assigned the Nom-Dat construction are not verbs whose object is necessarily human, as is the case with many dative-marked arguments in the world's languages. In fact, only two of the borrowed Nom-Dat verbs select for a human argument, namely msna 'communicate with somebody through MSN' and neimdroppa 'namedrop':

$$
\begin{aligned}
& \text { Leiðinlegt að msna fólki sem situr við hliðina á mér. } \\
& \text { boring to MSN people.DAT who sit with side on me } \\
& \text { 'It is so uninteresting to MSN people who sit beside me.' }
\end{aligned}
$$

$$
\begin{aligned}
& \text { Pú sýnir ekki einu sinni sóma pinn í að neimdroppa mér. } \\
& \text { you show not one time honor your in to namedrop me.DAT } \\
& \text { 'You don't even have the decency to namedrop me.' }
\end{aligned}
$$

The remaining Nom-Dat verbs select for ordinary non-human objects. Also, since most of these verbs are borrowed from English, which does not have a morphological dative, these verbs have not been borrowed together with their source language's verb-specific argument structure constructions, which would otherwise be a possibility (cf. Barðdal 2001b:132-3). Prior research on $15^{\text {th }}$-century Icelandic has shown the same tendency for borrowed verbs, namely that the dative object is 
not necessarily human (Barðdal 1999). Hence, dative case-marking of ordinary non-human objects is certainly not new in Icelandic.

Of the 107 borrowed verbs listed in (1)-(2) above, Icelandic speakers assign the Nom-Acc construction to 68 verbs and the Nom-Dat construction to 39. The proportion between the Nom-Acc and Nom-Dat is thus less than 2:1, which is certainly unexpected given that the dative is not reserved for human arguments. A question arises as to what the proportion between the type frequencies of NomAcc and Nom-Dat constructions is otherwise in Icelandic. I have elsewhere (Barðdal 2008:Ch. 3) carried out two counts of the transitive construction in Icelandic. One is based on the lexical entries in a recent bilingual Icelandic-English dictionary (Hólmarsson, Sanders, and Tucker 1989), and the other is based on a corpus of 40,000 running words from six different genres of Modern Icelandic texts (cf. Barðdal 2001b). The results are presented in Table 1 below:

Table 1. Nom-Acc and Nom-Dat in various counts of Icelandic

\begin{tabular}{lrrrrrr}
\hline & \multicolumn{2}{c}{ Dictionary Count } & \multicolumn{2}{c}{ Corpus Count } & \multicolumn{2}{c}{ Borrowed Verbs } \\
\hline & $\mathrm{N}$ & $\mathrm{f}$ & $\mathrm{N}$ & $\mathrm{f}$ & $\mathrm{N}$ & $\mathrm{f}$ \\
\hline Nom-Acc & 1,381 & $65.2 \%$ & 303 & $61.7 \%$ & 68 & $63.6 \%$ \\
Nom-Dat & 738 & $34.8 \%$ & 188 & $38.3 \%$ & 39 & $36.4 \%$ \\
Total & 2,119 & $100.0 \%$ & 491 & $100.0 \%$ & 107 & $100.0 \%$ \\
\hline
\end{tabular}

Observe that the figures for the borrowed verbs are in conformity with both the absolute figures from the dictionary count and the relative figures from the corpus count. Nom-Acc verbs are around 62-65\%, and Nom-Dat verbs around 35-38\%. The type frequency of both the Nom-Acc and the Nom-Dat construction is thus reflected in the type frequency of borrowed verbs. In other words, the productivity of the two constructions matches their type frequency in Modern Icelandic.

An analysis of the semantic range of the transitive construction in Icelandic only based on the 303 Nom-Acc and 188 Nom-Dat predicates occurring in the corpus of Modern Icelandic texts reveals that Nom-Acc verbs divide across 46 semantic verb classes and the Nom-Dat across 33 verb classes. Due to space limitations I cannot lay out the semantic structure of these constructions in a graphically coherent way here, but I refer the reader to Barðdal (2008:Ch. 3). At the highest schematic level, i.e. the event-type level, the Nom-Acc construction consists of at least six basic humanly relevant notions, i.e. MAKING, MOVEMENT, AFFECTEDNESS, COGNITION/EMOTION, CHANGE, and LOCATION. Each of these in turn consumes between two and twelve verb class-specific constructions, and one of the verb class-specific constructions under COGNITION/EMOTION can be divided into several verb subclass-specific constructions. In contrast, the Nom-Dat construction only subsumes three event-type constructions, i.e. CHANGE, COGNITION/EMOTION, and SUPERIORITY. There are also several Nom-Dat verb classspecific constructions which do not fall under any of these labels, nor do they make up an event type of their own. The Nom-Dat construction thus does not exist at as high a schematic level as the Nom-Acc construction. 


\section{Jóhanna Barðdal}

Notice that some of the general event-type categories are shared across the Nom-Acc and the Nom-Dat, e.g. COGNITION/EMOTION and CHANGE, which are found for both the Nom-Acc and the Nom-Dat construction. However, the subclasses are not necessarily the same for both constructions. The Nom-Acc verbs in (1) above belong to the following narrowly circumscribed semantic classes: verbs of attaching, attempting, building, cognition and mental activity, creation and reshaping, (means of) cutting, (de)limitation, destruction, displaying, producing, dwelling and keeping in place, emotion, feeding and consumption, (means) of gaining, increasing and strengthening, human manipulation, meeting and uniting, non-translational motion, physical affectedness, possession, catching and termination, (means of) traveling, and (interactive) verbal behavior.

The Nom-Dat verbs in (2) above belong to the following narrowly circumscribed semantic classes: verbs of destruction, division, starting and finishing, increase and decrease, losing, (caused) motion, non-translational motion, organizing, stealing, (means of) verbal communication, and changing. As evident from the lists in (1)-(2), some verbs are in fact listed twice, i.e. as taking both Nom-Acc and Nom-Dat. In those cases there is a clear difference in both semantic construal and subconstruction of the relevant argument structure construction. Consider the following two examples of bomba 'bomb':

Pá voru Kanarnir að bomba Júgóslava.

Affectedness

then were Americans to bomb Yugoslavians.ACC

'Then the Americans were bombing the Yugoslavians.'
Mér tókst aðbomba tannkremi í augaðá mér.
Caused-Motion me.DAT managed to bomb toothpaste.DAT into eye on me 'I managed to bomb toothpaste into my eye.'

In (5) bomba denotes affectedness, whereas in (6) it is used in the caused-motion construction, where the moved object is in the dative case (cf. Barðdal 2003).

Finally, consider the following example:

$$
\begin{aligned}
& \text { Vörubíllinn donaði uppi í brekkunni. } \\
& \text { truck.the dawned up in slope.the } \\
& \text { 'The truck ended up/was forgotten on the slope.' }
\end{aligned}
$$

In this example the English verb dawn has been borrowed into Icelandic and used as a particle verb dona uppi on the basis of the Icelandic particle verb daga uppi, which here means 'end up somewhere/be forgotten'. The predicate daga uppi consists of the simple verb daga meaning 'dawn' and the locative particle uppi 'up', originally used in reference to night trolls who were caught by daylight. Obviously, if one is a night troll and is caught by daylight, one does not constitute a threat to the environment anymore, and hence one may simply end up somewhere and gradually be forgotten. Observe, moreover, that the predicate daga uppi 'be 
caught by daylight, be forgotten' is a lexicalized idiom whose meaning is noncompositional and not derivable from the meaning of the parts. This is an idiosyncratic set phrase; hence, the formation of the predicate dona uppi is not based on a pattern, rule, or a super-ordinate schema, but on the already existing daga uppi and that alone. In other words, dona uppi is formed on the basis of the Icelandic expression daga uppi, where we find the lowest possible type frequency, i.e. one, and the highest possible degree of semantic coherence, i.e. full synonymy. This is therefore a clear-cut example of analogy, located at the bottom of the productivity cline in Figure 2 above.

In this section I have presented examples of three argument structure constructions in Icelandic: the Nom-Acc construction, which is a semantically open, high type-frequency construction; the Nom-Dat construction, which is a semantically more restricted construction of intermediate type frequency; and finally a specific example of a new particle verb with a very specific meaning, based on only one model verb. These three cases represent three points on the productivity cline, i.e. full productivity, intermediate productivity, and low productivity.

\section{Conclusions}

The extensibility of argument structure constructions is a function of their type frequency and semantic coherence, and an inverse correlation between the two. The current approach to syntactic productivity focusing on the EXTENSIBILITY concept offers a unified account of productivity since it captures different degrees of productivity ranging from highly productive patterns to various intermediate degrees of productivity to low-level analogical modeling. The REGULARITY and the GENERALITY concepts can also be derived from this analysis.

\section{References}

Barðdal, Jóhanna. 1999. Case and Argument Structure of Some Loan Verbs in 15th Century Icelandic. In I. Haskå and C. Sandqvist, eds., Alla tiders språk: En vänskrift till Gertrud Pettersson november 1999, 9-23. Lund: Institutionen för nordiska språk.

Barðdal, Jóhanna. 2000. Case Assignment of Nonce Verbs in Icelandic. SKY Journal of Linguistics 13:7-28.

Barðdal, Jóhanna. 2001a. The Perplexity of Dat-Nom Verbs in Icelandic. Nordic Journal of Linguistics 24:47-70.

Barðdal, Jóhanna. 2001b. Case in Icelandic: A Synchronic, Diachronic and Comparative Approach. Lund: Department of Scandinavian Languages.

Barðdal, Jóhanna. 2001c. The Role of Thematic Roles in Constructions? Evidence from the Icelandic Inchoative. In A. Holmer, J.-O. Svantesson, and Å. Viberg, eds., Proceedings of the 18th Scandinavian Conference of Linguistics 2000, 127-37. Lund: Department of Linguistics. 
Barðdal, Jóhanna. 2003. Case and Argument Structure of Novel Verbs of Communication in Icelandic. In L.-O. Delsing, C. Falk, G. Josefsson, and H. Á. Sigurðsson, eds., Grammar in Focus: Festschrift for Christer Platzack 18 November 2003, Vol. II, 25-35. Lund: Department of Scandinavian Languages.

Barðdal, Jóhanna. 2004. The Semantics of the Impersonal Construction in Icelandic, German and Faroese: Beyond Thematic Roles. In W. Abraham, ed., Focus on Germanic Typology, 105-37. Berlin: Akademie Verlag.

Barðdal, Jóhanna. 2006. Construction-Specific Properties of Syntactic Subjects in Icelandic and German. Cognitive Linguistics 17(1):39-106.

Barðdal, Jóhanna. 2007. The Lexical and Semantic Range of the Ditransitive Construction in the History of (North) Germanic. Functions of Language 14(1):9-30.

Barðdal, Jóhanna. 2008. Productivity: Evidence from Case and Argument Structure in Icelandic. Amsterdam: John Benjamins.

Barðdal, Jóhanna, and Valéria Molnár. 2003. The Passive in Icelandic - Compared to Mainland Scandinavian. In J. Hetland and V. Molnár, eds., Structures of Focus and Grammatical Relations, 231-60. Tübingen: Niemeyer.

Bauer, Laurie. 2001. Morphological Productivity. Cambridge: Cambridge UP.

Bybee, Joan. 1995. Regular Morphology and the Lexicon. Language and Cognitive Processes 10(5):425-55.

Clausner, Timothy C., and William Croft. 1997. Productivity and Schematicity in Metaphors. Cognitive Science 21(3):247-82.

Croft, William. 2001. Radical Construction Grammar: Syntactic Theory in Typological Perspective. Oxford: Oxford University Press.

Croft, William. 2003. Lexical Rules vs. Constructions: A False Dichotomy. In H. B. Cuyckens, Th. Berg, R. Dirven, and Kl.-U. Panther, eds., Motivation in Language: Studies in Honour of Günter Radden, 49-68. Amsterdam: John Benjamins.

Goldberg, Adele E. 1995. Constructions: A Construction Grammar Approach to Argument Structure. Chicago: University of Chicago Press.

Hólmarsson, Sverrir, Christopher Sanders, and John Tucker. 1989. Íslensk-ensk orðabók: Concise Icelandic-English Dictionary. Reykjavík: Iðunn.

Ragnarsdóttir, Hrafnhildur, Hanne Gram Simonsen, and Kim Plunkett. 1999. The Acquisition of Past Tense Morphology in Icelandic and Norwegian Children: An Experimental Study. Journal of Child Language 26:577-618.

Jóhanna Barðdal

Department of Linguistic, Literary and Aesthetic Studies

University of Bergen

P.O. Box 7805

N-5020 Bergen, Norway

johanna.barddal@uib.no 